\title{
PENGARUH KOMBINASI TEKNIK PERNAPASAN BUTEYKO DAN LATIHAN BERJALAN TERHADAP KONTROL ASMA PADA PASIEN ASMA DEWASA
}

\section{The Effect of Combination of Buteyko Breathing Technique And Walking Exercise on Asthma Control in Adult Asthmatic Patients}

\section{Wiwik Udayani ${ }^{* 1}$, Muhammad Amin'2, Makhfudli ${ }^{3}$}

1. Magister Keperawatan, Faculty of Nursing, Universitas Indonesia

2. Faculty of Medicine, Universitas Airlangga, Surabaya

3. Faculty of Nursing, Universitas Airlangga, Surabaya

\section{Riwayat artikel}

Diajukan: 8 Juli 2019

Diterima: 28 Maret 2020

\section{Penulis Korespondensi:}

- Wiwik Udayani

- Magister Keperawatan, Faculty of Nursing, Universitas Indonesia

- wiwikudayani2008@gm ail.com

\section{Kata Kunci:}

self efficacy, caregiver, skizofrenia, kesejahteraan psikologis

\section{Abstrak}

Pendahuluan: Melakukan latihan napas dan latihan fisik yang rutin dapat meningkatkan kontrol asma. Latihan yang dapat dilakukan adalah kombinasi teknik pernapasan Buteyko dan latihan berjalan. Tujuan penelitian ini adalah menganalisis pengaruh kombinasi teknik pernapasan Buteyko dan latihan berjalan terhadap kontrol asma. Metode: Desain penelitian ini adalah quasi experimental dengan pretest-postest control group design. Lokasi penelitian di klinik paru RSUD Kabupaten Sidoarjo dan RSUD Bangil Kabupaten Pasuruan, Jawa Timur. Responden diseleksi dengan randomisasi dengan simple random sampling. Responden dalam penelitian ini berjumlah 76 responden. Data kontrol asma diukur dengan menggunakan Asthma Control Test (ACT). Kelompok intervensi diberikan latihan kombinasi teknik pernapasan Buteyko dan latihan berjalan selama 8 minggu, 3x per minggu, 55 menit tiap sesi latihan. Pemberian latihan kombinasi teknik pernapasan Buteyko dan latihan berjalan menggunakan media modul dan video. Pengukuran kontrol asma dilakukan 3 kali pengukuran (pre test, minggu ke 4, minggu ke 8). Data dianalisis menggunakan SPSS 22 dengan GLM-RM (General Linear Model-Repeated Measure) ANOVA. Hasil: Hasil penelitian menunjukkan perbedaan yang signifikan nilai kontrol asma antara sebelum dan sesudah 4 minggu dan 8 minggu intervensi pada kelompok perlakuan dengan didapatkan nilai $\mathrm{p}=0.000(\mathrm{p}<0,05)$. Diskusi: Kombinasi teknik pernapasan Buteyko dan latihan berjalan meningkatkan kontrol asma melaui mekanisme peningkatan $\mathrm{CO}_{2}$ dan produksi nitric oxide yang berefek bronkodilatasi dan melalui penurunan mediator inflamasi sehingga dapat menurunkan gejala asma.

\section{Abstract}

Introduction: Doing breathing exercises and regular physical exercise can increase asthma control. Exercises that can be done are a combination of Buteyko breathing techniques and walking exercises. The purpose of this study was to analyze the effect of a combination of Buteyko breathing techniques and walking exercises on athma control. Methods: The design of this study was quasi experimental with pretest-posttest control group design. The location of the study was in the pulmonary clinic of Regional General Hospital of Sidoarjo Regency and Bangil Regional General Hospital in Pasuruan Regency, East Java. Respondents were selected by randomization by simple random sampling. Respondents in this study amounted to 76 respondents. Asthma control were measured using Asthma Control Test. The intervention group was given a combination exercise with Buteyko breathing technique and walking exercise for 8 weeks, 3x per week, 55 minutes every training session. Giving a combination of Buteyko breathing technique and walking exercises using module and video media. Asthma control measurements were carried out 3 times (pre test, week 4, week 8). Data were analyzed using SPSS 22 with GLM-RM (General Linear Model-Repeated Measure) ANOVA. Result: The research results showed a significant difference in the astma control value between before and after 4 weeks and 8 weeks of the intervention in the treatment group with $p=0.000(p$ $<0.05)$. Discussion:The combination of Buteyko breathing techniques and walking exercise increase asthma control through the mechanism of increasing $\mathrm{CO} 2$ and producing nitric oxide which has bronchodilation effects and through decreasing inflammatory mediators so that it can reduce asthma symptoms.. 


\section{PENDAHULUAN}

Tujuan penatalaksanaan asma jangka panjang adalah mencapai asma tekontrol. Kontrol asma diperlukan untuk meminimalkan risiko eksaserbasi dan penurunan fungsi paru sehingga pasien asma dapat beraktivitas secara optimal dalam kehidupan sehari-hari (GINA, 2018). Kontrol asma yang buruk dapat menurunkan kualitas hidup pasien asma (GINA, 2018). Kontrol asma yang buruk dan eksaserbasi asma akan menimbulkan airway remodeling dan penurunan fungsi paru (Reddel et al., 2009). Diperkirakan 235 juta manusia hidup dengan asma dan negara dengan penghasilan menengah kebawah sekitar $80 \%$ asma berhubungan dengan kematian (WHO, 2018) . Pada tahun 2025 diperkirakan prevalensi asma di dunia mengalami peningkatan mencapai 400 juta orang (Masoli, Fabian, Holt, Beasley, 2004). Sedangkan menurut Riset Kesehatan Dasar Tahun 2013 penyakit asma di Indonesia menempati urutan tertinggi untuk kategori penyakit tidak menular sebesar 4,5\% dan di Jawa Timur prevalensi asma sebesar 5,1 \%. Penelitian di Asia Pasifik menunjukkan bahwa kontrol asma buruk sebesar $21 \%$, asma yang tidak terkontrol dengan baik sebesar 59\% dan 33\% responden mengungkapkan bahwa gejala asma muncul pada malam hari atau dini hari sekali atau lebih dalam seminggu (Lai et al., 2006). Penelitian tentang tingkat kontrol asma di Klinik Asma Rumah Sakit Persahabatan Jakarta dengan menggunakan kuesioner Asthma Control Test menunjukkan asma tidak terkontrol sebesar $75,5 \%$ atau 81 responden dari 107 responden (Atmoko dkk., 2011)

Penatalaksanaan farmakologis asma sangat bermanfaat bila terjadi serangan asma. Kelemahan dari penggunaan terapi farmakologi jangka panjang yaitu memiliki efek samping terutama jika tidak melakukan kontrol pengobatan (Ducharme dan Hicks, 2000). Jenis penelitian ini adalah quasi experimental dengan pretest - postest control group design. Nilai kontrol asma diukur dalam pre test dan post test $2 \mathrm{x}$ yaitu minggu ke 4 dan minggu ke 8 . Kelompok perlakuan diberikan intervensi kombinasi teknik pernapasan Buteyko dan latihan berjalan selama 8 minggu yang dilakukan secara mandiri di rumah. Sebelum melakukan intervensi secaa mandiri di rumah responden diberikan pelatihan kombinasi teknik pernapasan Buteyko dan latihan berjalan dengan menggunakan media modul latihan dan video.
Penatalaksanaan nonfarmakologis dikembangkan sebagai pelengkap farmakologi untuk meningkatkan kontrol asma (Hall et al., 2017). Penatalaksanaan nonfarmakologis dapat dilakukan melalui aktivitas fisik dan latihan napas (GINA, 2018). Latihan napas yang direkomendasikan untuk asma adalah teknik pernapasan Buteyko (Godfrey, 2010). Banyak penelitian tentang teknik pernapasan Buteyko baik di luar negeri maupun Indonesia dan hasil menunjukkan teknik Buteyko dapat meningkatkan kontrol asma. Teknik Buteyko dapat menurunkan gejala asma, menurunkan penggunaan bronkodilator namun sedikit dan tidak signifikan dalam mengurangi responsifitas bronkial (Cooper et al., 2003; Mohamed, Riad dan Ahmed, 2013). Latihan fisik yang melengkapi latihan napas dalam rehabilitasi paru dapat meningkatkan kontrol asma (Juhariyah dkk., 2012). Latihan fisik berupa berjalan meningkatkan kontrol asma dengan mengurangi reaksi hiperesponsivitas dan meningkatkan daya tahan kardiorespirasi (Pakhale, Luks, Burkett, \& Turner, 2013). Namun kombinasi kedua latihan ini belum pernah diteliti.

Sebagai petugas kesehatan professional perawat mempunyai peranan dalam membantu pasien asma mempunnyai self care agency dimana perawat berperan dalam supportive educative terkait rehabilitasi paru. Teori Self care Orem diaplikasikan dalam pelaksanaan pulmonary rehabilitasi pasien asmaKombinasi teknik pernapasan Buteyko dan latihan berjalan merupakan latihan yang mudah untuk dilakukan dan tidak membutuhkan biaya sehingga dapat dilakukan pasien secara mandiri di rumah. Penelitian ini bertujuan menganalisis pengaruh kombinasi teknik pernapasan Buteyko dan latihan berjalan terhadap kontrol asma.

\section{METODE}

Peneliti mengajarkan cara menilai batas toleransi latihan berjalan yaitu $60-80 \%$ denyut jantung maksimal. Penghitungan denyut jantung maksimal dengan menggunakan rumus 220-usia. Penilaian batas toleransi dilakukan setiap 6 menit sekali selama latihan berjalan.

Latihan yang meliputi teknik pernapasan Buteyko dilakukan selama 15 menit, latihan berjalan selama 40 menit (5 menit pemanasan, 30 menit berjalan, 5 menit pendinginan) sehingga total latihan 55 menit. Latihan dilakukan 3x/minggu selama 8 minggu. Peneliti melakukan 
kunjungan rumah tiap $1 \mathrm{x} /$ minggu untuk mengevaluasi ketepatan latihan yang sedang dilakukan dan perkembangan kondisi pasien. Peneliti menganjurkan responden mengisi format checklist latihan sesuai jadwal latihan. Peneliti mengingatkan responden baik melalui telepon, sms, maupun media sosial untuk melakukan latihan secara mandiri sesuai arahan peneliti. Peneliti juga melibatkan keluarga responden dalam mengingatkan responden untuk melakukan latihan. Kelompok perlakuan dilakukan di Klinik Paru Rumah Sakit Umum Daerah Kabupaten Sidoarjo. Kelompok kontrol tidak diperkenankan melakukan latihan napas dan atau latihan fisik lainnya. Kelompok kontrol dilakukan di Klinik Paru Rumah Sakit Umum Daerah Bangil Kabupaten Pasuruan.

Populasi dalam penelitian ini adalah pasien dewasa yang didiagnosis asma oleh dokter spesialis paru di Poliklinik Paru RSUD Kabupaten Sidoarjo dan RSUD Bangil Kabupaten Pasuruan dengan menggunakan anamnesis, pemeriksaan fisik, dan tes spirometri. Sampel dalam penelitian ini diambil dari populasi dengan kriteria inklusi dan eksklusi, yaitu:

\section{Kriteria Inklusi}

1) Pasien asma yang berusia 18-60 tahun.

2) Asma stabil

3) Fungsi pendengaran dan penglihatan baik

4) Mempunyai fisik dan mental yang sehat

5) Pasien belum pernah mengikuti latihan napas dan atau latihan fisik

2. Kriteria Eksklusi

1) Pasien merokok

2) Pasien asma yang mengalami obesitas

3) Asma dalam kehamilan

4) Mempunyai penyakit paru lainnya seperti TB paru, PPOK, karsinoma paru

5) Mempunyai penyakit hipertensi, gagal jantung, epilepsi, kelainan muskuloskeletal

3. Kriteria drop out

1) Responden melakukan latihan pernapasan dan latihan fisik lainnya selama penelitian

2) Responden tidak mengikuti tahapan intervensi secara lengkap

3) Responden mengundurkan diri dengan berbagai alasan

4) Responden yang mengalami kekambuhan saat latihan

Teknik sampel menggunakan probability sampling dengan simple random sampling. Besar sampel didapatkan melalui rumus besar sampel untuk uji hipotesis beda proporsi 2 kelompok data berpasangan (M. S. Dahlan, 2013). Besar sampel dalam penelitian ini adalah 38 responden untuk kelompok perlakuan dan 38 responden untuk kelompok kontrol. Sampel diambil menggunakan. Pengukuran kontrol asma mneggunakan Asthma Control Test (ACT). Uji Statistik menggunakan General Linear ModelRepeated Measured ANOVA within subject untuk mengetahui perbedaan nilai Puncak Ekspirasi Paksa pre-test dan post-test dalam tiap kelompok. Uji General Linear Model-Repeated Measured ANOVA between subject digunakan untuk perbedaan nilai kontrol asma pre-test dan post-test antar kelompok perlakuan dan kelompok kontrol (Dahlan, 2014).

Persetujuan etik dikeluarkan oleh Komite Etik Penelitian Kesehatan (KEPK) RSUD Kabupaten Sidoarjo dengan Nomor: 893.3/0332/438.6.7/2019 dan oleh Tim Etik Penelitian Kesehatan RSUD Bangil Kabupaten Pasuruan Nomor: 445.1/570.2/424.202/2019

\section{PEMBAHASAN}

Kontrol asma adalah suatu keadaan yang menunjukkan gejala asma minimal atau tidak ada termasuk gejala pada malam hari, tidak ada keterbatasan aktivitas termasuk exercise, kebutuhan bronkodilator (agonis $\beta_{2}$ kerja singkat) minimal atau tidak diperlukan, variasi harian APE kurang dari $20 \%$, nilai APE normal atau mendekati normal, obat samping obat minimal atau tidak ada, tidak ada kunjungan gawat darurat (PDPI, 2012).

Lima item penilaian untuk mengukur tingkat kontrol asma menggunakan ACT (Asthma Control Test) yaitu intensitas kekambuhan asma dalam melakukan pekerjaan sehari-hari, mengalami sesak napas, terbangun pada malam hari, penggunaan obat dan persepsi tingkat kontrol asma. Pada beberapa pertanyaan pada ACT berkaitan dengan eksaserbasi/kekambuhan asma yaitu sebuah proses serangan berulang akibat hiperesponsif sel imun tubuh seperti sel mast, eosinophil dan limfosit $T$, sel mast, makrofag, sel dendritic, dan miofibroblas terhadap stimulus tertentu sehingga menyebabkan gejala sesak napas, wheezing dan batuk yang merupakan akibat dari terjadinya penyempitan saluran napas (Barnes, 2015). 
Tabel 1 Karakteristik Responden

\begin{tabular}{|c|c|c|c|c|c|}
\hline \multirow[t]{2}{*}{ Karakteristik } & \multicolumn{2}{|c|}{$\begin{array}{l}\text { Kelompok } \\
\text { Perlakuan }\end{array}$} & \multicolumn{2}{|c|}{$\begin{array}{l}\text { Kelompok } \\
\text { Kontrol }\end{array}$} & \multirow{2}{*}{$\begin{array}{l}\text { Uji } \\
\text { Homogenitas }\end{array}$} \\
\hline & $\mathrm{f}$ & $\%$ & $\mathrm{f}$ & $\%$ & \\
\hline \multicolumn{6}{|l|}{ Usia (tahun) } \\
\hline $18-25$ & 1 & 2.6 & 1 & 2.6 & \multirow{6}{*}{0.510} \\
\hline $26-35$ & 9 & 23.7 & 10 & 26.3 & \\
\hline $36-45$ & 15 & 39.5 & 6 & 15.8 & \\
\hline $46-55$ & 10 & 26.3 & 12 & 31.6 & \\
\hline $56-60$ & 3 & 7.9 & 9 & 23.7 & \\
\hline Total & 38 & 100 & 38 & 100 & \\
\hline \multicolumn{6}{|l|}{ Jenis Kelamin } \\
\hline Laki-laki & 10 & 26.3 & 13 & 34.2 & \multirow{3}{*}{0.144} \\
\hline Perempuan & 28 & 73.7 & 25 & 65.8 & \\
\hline Total & 38 & 100 & 38 & 100 & \\
\hline \multicolumn{6}{|l|}{ Pendidikan } \\
\hline SLTP & 3 & 7.9 & 17 & 44.7 & \multirow{4}{*}{0.098} \\
\hline SLTA & 13 & 34.2 & 12 & 31.6 & \\
\hline PT & 22 & 57.9 & 9 & 23.7 & \\
\hline Total & 38 & 100 & 38 & 100 & \\
\hline \multicolumn{6}{|l|}{ Pekerjaan } \\
\hline Bekerja & 31 & 81.6 & 23 & 60.5 & \multirow[t]{3}{*}{0.574} \\
\hline Tidak bekerja & 7 & 18.4 & 15 & 39.5 & \\
\hline Total & 38 & 100 & 38 & 100 & \\
\hline \multicolumn{6}{|l|}{ Indeks Masa Tubuh } \\
\hline Kurus: $\leq 18.5$ & 2 & 5.2 & 4 & 10.5 & \multirow{4}{*}{0.267} \\
\hline Normal: 18.6-24.9 & 18 & 47.4 & 13 & 34.2 & \\
\hline Gemuk: 25-29.9 & 18 & 47.4 & 21 & 55.3 & \\
\hline Total & 38 & 100 & 35 & 100 & \\
\hline
\end{tabular}

Tabel 2 Nilai kontrol asma kelompok perlakuan dan kelompok control

\begin{tabular}{|c|c|c|c|c|c|c|c|c|c|c|c|c|}
\hline \multirow[b]{2}{*}{$\begin{array}{l}\text { Kontrol } \\
\text { asma }\end{array}$} & \multicolumn{6}{|c|}{ Kelompok Perlakuan } & \multicolumn{6}{|c|}{ Kelompok Kontrol } \\
\hline & $\begin{array}{l}\text { Pre } \\
\text { test }\end{array}$ & $\%$ & $\begin{array}{c}\text { Minggu } \\
\text { ke } 4\end{array}$ & $\%$ & $\begin{array}{c}\text { Minggu } \\
\text { ke } 8\end{array}$ & $\%$ & $\begin{array}{l}\text { Pre } \\
\text { test }\end{array}$ & $\%$ & $\begin{array}{c}\text { Minggu } \\
\text { ke } 4\end{array}$ & $\%$ & $\begin{array}{c}\text { Minggu } \\
\text { ke } 8\end{array}$ & $\%$ \\
\hline $\begin{array}{l}\text { Tidak } \\
\text { terkontrol }\end{array}$ & 28 & 73.7 & 24 & 63.2 & 15 & 39.5 & 33 & 86.8 & 33 & 86.8 & 33 & 86.8 \\
\hline $\begin{array}{l}\text { Terkontrol } \\
\text { sebagian }\end{array}$ & 10 & 26.3 & 7 & 18.4 & 13 & 34.2 & 5 & 13.2 & 5 & 13.2 & 5 & 13.2 \\
\hline $\begin{array}{l}\text { Terkontrol } \\
\text { penuh }\end{array}$ & - & - & 7 & 18.4 & 10 & 26.3 & - & - & - & - & - & - \\
\hline
\end{tabular}

Tabel 3 Hasil uji GLM-RM (General Linear Model-Repeated Measure) ANOVA within subject

\begin{tabular}{ccccc}
\hline Kelompok & $\begin{array}{c}\text { Peruhahan nilai kontrol } \\
\text { asma }\end{array}$ & Mean \pm SD & Selisih rerata & Nilai p \\
\hline \multirow{3}{*}{ Perlakuan } & Pre vs minggu ke 4 & $15.37 \pm 5.294$ & 2.45 & 0.000 \\
& Pre vs minggu ke 8 & $17.82 \pm 5.013$ & 4.87 & 0.000 \\
& Minggu ke 4 vs minggu & $20.24 \pm 3.983$ & 2.42 & 0.000 \\
\hline \multirow{2}{*}{ ke 8 } & Pre vs minggu ke 4 & $14.34 \pm 4.035$ & 0.21 & 0.899 \\
& Pre vs minggu ke 8 & $14.55 \pm 3.718$ & 0.27 & 1.000 \\
\hline
\end{tabular}


Table 4 Hasil uji GLM-RM (General Linear Model-Repeated Measure) ANOVA between subject

\begin{tabular}{ccccc}
\hline $\begin{array}{c}\text { APEP } \\
(\mathrm{L} / \mathrm{menit})\end{array}$ & $\begin{array}{c}\text { Perlakuan } \\
\text { Mean } \pm \text { SD }\end{array}$ & $\begin{array}{c}\text { Kontrol } \\
\text { Mean } \pm \text { SD }\end{array}$ & $\begin{array}{c}\text { Selisih (confidence interval 95 } \\
\text { \%) }\end{array}$ & Nilai $\mathrm{p}$ \\
\hline Pretest & $15.37 \pm 5.294$ & $14.34 \pm 4.035$ & $1.03(-1.125-3.178)$ & 0.345 \\
Minggu ke 4 & $17.82 \pm 5.013$ & $14.55 \pm 3.718$ & $3.27(1.246-5.280)$ & 0.002 \\
Minggu ke 8 & $20.24 \pm 3.983$ & $14.61 \pm 3.760$ & $5.53(3.842-7.421)$ & 0.000 \\
\hline Uji General Linear Model $\mathrm{p}=0.000$ (post hoc analysed) &
\end{tabular}

Uji General Linear Model p $=0.000$ (post hoc analysed)

Peningkatan nilai kontrol asma pada kelompok perlakuaan dapat dipengaruhi karakateristik atau faktor sosio demografik yaitu usia, jenis kelamin, pendidikan, Indeks Masa Tubuh (IMT). responden pada kelompok perlakuan hampir sebagian berada pada pada rentang usia 36-45 tahun yaitu 15 (39.5\%). Asma di usia tua diperberat dengan adanya perubahan pada sistem respirasi sehingga menyebabkan asma lebih sulit terkontrol (Hanania et al., 2011). Hampir sebagian responden yang berada pada kategori dewasa akhir dimana saluran pernapasan masih relatif dalam kondisi baik sehingga asma akan mudah menjadi terkontrol. Karakteritik tingkat pendidikan responden pada kelompok perlakuan lebih dari sebagian berpendidikan perguruan tinggi sebanyak 22 responden (57.9 \%). Pasien dengan tingkat pendidikan tinggi kemungkinan lebih memahami dan patuh terhadap program pengobatan (Starobin et al, 2007). Lebih dari sebagian responden yang berpendidikan tinggi akan lebih mudah memahami dan patuh terhadap program pengobatan sehingga asma akan lebih mudah menjadi terkontrol. Karakteristik responden berdasarkan Indeks Masa Tubuh (IMT) pada kelompok perlakuan hampir sebagian pada kategori normal (18.6-24.9) sebanyak 18 responden (47.4\%). Asma lebih sulit dikontrol pada pasien obesitas (GINA, 2018). Pada pasien asma dengan obesitas berkaitan dengan peningkatan adipokin. Hampir sebagian kelompok perlakuan pada kategori normal dimana tidak terjadi peningkatan adipokin maka asma lebih mudah terkontrol.

Perubahan kontrol asma pada kelompok perlakuan lebih besar dibandingkan kelompok kontrol. Maka dapat disimpulkan pasien asma yang diberikan latihan kombinasi teknik pernapasan Buteyko dan latihan berjalan memiliki nilai kontrol asma yang lebih besar dibandingkan dengan pasien asma yang tidak diberikan latihan kombinasi teknik pernapasan Buteyko dan latihan berjalan.

Penelitian yang dilakukan Cowie et al (2008) menunjukkan bahwa teknik pernapasan Buteyko dapat meningkatkan kontrol asma dan mengurangi penggunaan kortikosterois inhlasi. Penelitian juga didukung oleh Prem et al (2012) menunjukkan bahwa teknik pernapasan Buteyko dapat meningkatkan kualitas hidup pasien asma, kontrol asma, dan fungsi paru. Penelitian yang dilakukan Mohamed, Riad dan Ahmed (2013) menunjukkan bahwa teknik pernapasan Buteyko dapat kontrol asma. Kelebihan teknik pernapasan Buteyko adalah control pause yang dapat mengurangi pengeluaran $\mathrm{CO}_{2}$ berlebihan yang akan mengatur kembali pernapasan melalui pusat pernapasan di medulla, menghasilkan nitric oxide (NO) yang berefek bronkodilatasi. Latihan fisik berupa berjalan dapat meningkatkan fungsi paru dan kontrol asma dengan mengurangi reaksi hiperesponsivitas dan meningkatkan daya tahan kardiorespirasi (Pakhale et al., 2013).

Melalui mekanisme teknik menahan napas pada kapasitas residual fungsional dan mouthtapping pada malam hari yaitu tidur dengan posisi miring ke kiri dan mencegah tidur terlentang karena dapat menyebabkan hiperventilasi. Kedua teknik ini akan meningkatkan tekanan $\mathrm{CO}_{2}$ arterial dan alveolar (Cooper, et al, 2003). Penelitian yang dilakukan Lina, et al, (2015) bahwa teknik Buteyko dapat meningkatkan kontrol asma dan kualitas hidup pada pasien asma anak melalui mekanisme menghembus napas normal kemudian menahan napas sampai pertama kali merasa tidak nyaman atau ingin bernapas kembali. Waktu ini dicatat sebagai control pause. Pada orang sehat mampu mencapai 50-60 detik, tetapi pada penderita asma sedang sampai berat seringkali hanya mampu 1-3 detik. Kemudian diikuti dengan bernapas pelan dan tidak dalam melalui hidung atau disebut shallow breathing. Kemudian dilanjutkan dengan aktifitas fisik untuk meningkatkan $\mathrm{CO}_{2}$. Peningkatan $\mathrm{CO}_{2}$ akan menimbulkan dilatasi pada otot polos pada dinding bronkus, bronkiolus, alveolar sehingga terjadi keseimbangan ventilasi perfusi (Prem, et al., 2012). Teknik buteyko juga mengajarkan bernapas melalui hidung karena akan dapat membawa keuntungan yaitu memfiltrasi udara dari allergen dan polusi debu, humidifikasi, dan menghasilkan nitric oxide yang akan menghasilkan bronkodilatasi saluran napas. 
Peningkatan kadar $\mathrm{CO}_{2}$ dan nitric oxide yang dihasilkan dari teknik Buteyko dapat melebarkan saluran pernapasan sehingga pasien asma dapat melakukan pekerjaan sehari-hari tanpa ada keluhan mengi atau wheezing, sesak napas, batuk, dan nyeri dada. Pasien asma juga dapat mencapai kualitas tidur yang baik karena berkurangnya gejala asma. Berkurangnya gejala asma akan mengurangi dosis bronkodilator yang digunakan sehingga dapat menghemat layanan kesehatan.

Asma merupakan penyakit inflamasi kronis pada saluran napas yang ditandai dengan obstruksi saluran napas dan hiperesponsifitas bronkial (GINA, 2018). Latihan yang dapat mengurangi hiperesponsif saluran napas dan inflamasi sistemik dengan pengurangan nilai IL6 dan monocyte chemoattractan protein 1 (CMP1) adalah aerobik (França-Pinto et al., 2015). Latihan aerobik yang mudah dilakukan dan dikendalikan adalah latihan berjalan (Hall et al., 2017). Penelitian yang dilakukan oleh Boyd et al., (2012) menunjukkan bahwa latihan berjalan dapat meningkatkan kontrol asma dan level cardiopulmonary fitness tanpa menyebabkan gangguan pada penderita asma dewasa. Kondisi inflamasi pada asma dapat berkurang karena efek latihan berjalan yaitu dengan mengurangi mediator inflamasi berupa IL-6 dan monocyte chemoattractan protein 1 (CMP-1) Teknik pernapasan Buteyko yang dikombinasikan dengan latihan berjalan akan dapat meningkatkan kontrol asma.

Kontrol asma yang meningkat secara bertahap dapat dikaitkan dengan intensitas latihan. Pada awal latihan pasien dianjurkan melakukan latihan dengan intensitas ringan kemudian dapat ditingkatkan sesuai dengan kemampuan pasien. Latihan yang tidak dilakukan secara bertahap dapat menimbulkan exercise induce asthma. Pasien asma yang rutin melakukan latihan secara bertahap dapat mengukur kemampuan dirinya dalam melakukan latihan tanpa mengalami kelelahan akibat latihan dan pasien dapat merasakan efek positif dari latihan yang dilakukan. Pasien asma yang dapat mengontrol tingkat asmanya akan lebih mudah melakukan self care secara mandiri di rumah.

Pada kelompok kontrol mengalami peningkatan nilai kontrol asma. Hal ini terjadi karena semua responden dalam kelompok kontrol masih mendapatkan pengobatan asma.

Pada kelompok kontrol mengalami penurunan nilai kontrol asma. Latihan napas dan aktivitas fisik atau exercise yang tidak dilakukan oleh pasien asma berdampak pada kelemahan otototot pernapasan sehingga terjadi penurunan fungsi paru, selain itu gangguan pernapasan dan gejala sesak napas akan meningkat serta toleransi terhadap aktivitas menurun (Sahat, Irawaty, \& Hastono, 2011). Pasien asma yang tidak melakukan latihan napas secara teratur dapat memperberat gejala sesak napas yang muncul saat serangan karena pasien tersebut tidak mengetahui teknik pernapasan yang benar. Hal ini dapat menimbulkan ketidakseimbangan ventilasi-perfusi pada paru.

\section{KESIMPULAN DAN SARAN Kesimpulan}

Kombinasi teknik pernapasan Buteyko dan latihan berjalan meningkatkan kontrol asma melaui mekanisme peningkatan $\mathrm{CO}_{2}$ dan produksi nitric oxide yang berefek bronkodilatasi dan melalui penurunan mediator inflamasi sehingga dapat menurunkan gejala asma.

\section{Saran}

Pasien asma dapat menjadikan kombinasi teknik pernapasan Buteyko dan latihan berjalan yang dilakukan $3 \mathrm{x} /$ minggu dengan lama latihan 55 menit sebagai penunjang terapi farmakologis untuk meningkatkan dan kontrol asma. Latihan ini merupakan latihan yang aman, mudah untuk dilakukan, dan tidak membutuhkan biaya. Layanan kesehatan dapat menerapkan dan memberikan edukasi pada pasien asma terkait latihan kombinasi teknik pernapasan Buteyko dan latihan berjalan untuk meningkatkan kontrol asma.

\section{DAFTAR PUSTAKA}

Atmoko, W., Faisal, H. K. P., Bobian, E. T., Adisworo, M. W., \& Yunus, F. (2011). Prevalens asma tidak terkontrol dan faktorfaktor yang berhubungan dengan tingkat kontrol asma di poliklinik asma rumah sakit persahabatan, jakarta. $J$ Respir Indo, 31(2), 53-60.

Boyd, A., Yang, C. T., Estell, K., MS, C., Gerald, L. B., Dransfield, M., ... Schwiebert, L. M. (2012). Feasibility of exercising adults with asthma: a randomized pilot study. Allergy, Asthma \& Clinical Immunology, $8(1), \quad 13$. https://doi.org/10.1186/17101492-8-13

Cooper, S., Oborne, J., Newton, S., Harrison, V., Coon, J. T., Lewis, S., \& Tattersfield, A. (2003). Effect of two breathing execise (Buteyko and Pranayama) in asthma: a randomized controlled trial. Thorax, 674679.

Dahlan, M. (n.d.). Sopiyudin, 2014. Statistik Untuk Kedokteran Dan Kesehatan, 
Deskriptif, Bivariat, Dan Multivariat Dilengkapi Aplikasi Dengan Menggunakan SPSS, 1-47.

Dahlan, M. S. (2013). Besar sampel untuk desain khusus. Dalam: Aklia S, Penyunting. Besar Sampel Dan Cara Pengambilan Sampel Dalam Penelitian Kedokteran Dan Kesehatan. Seri Evidence Based Medicine, 2, 81-115.

Ducharme, F. M., \& Hicks, G. C. (2000). Antileukotriene agents compared to inhaled corticosteroids in the management of recurrent and/or chronic asthma. The Cochrane Database of Systematic Reviews, (3), CD002314-CD002314.

França-Pinto, A., Mendes, F. A. R., de CarvalhoPinto, R. M., Agondi, R. C., Cukier, A., Stelmach, R., ... Carvalho, C. R. F. (2015). Aerobic training decreases bronchial hyperresponsiveness and systemic inflammation in patients with moderate or severe asthma: a randomised controlled trial. Thorax, 70(8), 732-739. https://doi.org/10.1136/thoraxjnl-2014206070

Ghebre, M. A., Bafadhel, M., Desai, D., Cohen, S. E., Newbold, P., Rapley, L.,Brightling, C. E. (2015). Biological clustering supports both "dutch" and "british" hypotheses of asthma and chronic obstructive pulmonary disease. Journal of Allergy and Clinical Immunology, 135(1), 63-72.e10.

https://doi.org/10.1016/j.jaci.2014.06.035

GINA. (2018). Global Strategy for Asthma Management and Prevention.

Godfrey, K. (2010). The Buteyko technique in asthma management. Practice Nursing, 21(5), 238-242. Retrieved from http://www.resmedjournal.com/article/S0 954-6111(07)00511-2/fulltext

Hall, C., Nici, L., Sood, S., Zuwallack, R., Castro, M., \& Louis, S. (2017). Nonpharmacologic Therapy for Severe Persistent Asthma. The Journal of Allergy and Clinical Immunology: In Practice, 5(4), 928-935. https://doi.org/10.1016/j.jaip.2017.04.030

Juhariyah, S., Djajalaksana, S., Sartono, T. R., \& Ridwan, M. (2012). Efektivitas Latihan
Fisis dan Latihan Pernapasan pada Asma Persisten Sedang-Berat. J Respir Indo, 32(1), 17-24.

Lai, C. K. W., Kuo, S. H., De Guia, T., Lloyd, A., Williams, A. E., \& Spencer, M. D. (2006). Asthma control and its direct healthcare costs: findings using a derived Asthma Control TestTM score in eight Asia-Pacific areas. European Respiratory Review, 15(98), 24-29.

Masoli, M., Fabian, D., Holt, S., Beasley, R., (GINA). (2004). The global burden of asthma: executive summary of the GINA Dissemination Committee report. Allergy, 59(5), 469-478.

Mohamed, Z., Riad, N. M., \& Ahmed, F. H. (2013). Effect of Buteyko breathing technique on patients with bronchial asthma. Egyptian Journal of Chest Diseases and Tuberculosis, 61(4), 235241.https://doi.org/10.1016/j.ejcdt.2012.0 8.006

Pakhale, S., Luks, V., Burkett, A., \& Turner, L. (2013). Effect of physical training on airway inflammation in bronchial asthma: A systematic review. BMC Pulmonary Medicine, 13(1), 1 . https://doi.org/10.1186/1471-2466-13-38

PDPI. (2012). Pedoman Praktis Diagnosis dan Penatalaksanaan di Indonesia. Jakarta: Departemen Kesehatan Republik Indonesia.

Reddel, H. K., Taylor, D. R., Bateman, E. D., Boulet, L.-P., Boushey, H. A., Busse, W. W., Gibson, P. G. (2009). An official American Thoracic Society/European Respiratory Society statement: asthma control and exacerbations: standardizing endpoints for clinical asthma trials and clinical practice. American Journal of Respiratory and Critical Care Medicine, 180(1), 59-99.

Sahat, C. S., Irawaty, D., \& Hastono, S. P. (2011). Peningkatan kekuatan otot pernapasan dan fungsi paru melalui senam asma pada pasien asma. Jurnal Keperawatan Indonesia, 14, 101-106.

WHO | Asthma. (2013). WHO. Retrieved from http://www.who.int/respiratory/asthma/en/ 
Jurnal Ilmiah Keperawatan (Scientific Journal of Nursing), Vol 6, No 1, Tahun 2020 